Inna A. KIVENKO,

Assistant Professor of the Professional English Language Department in Odessa National Maritime University; 34

Mechnikova St., Odessa, 65029, Ukraine; phone: +38 093 7937627; e-mail: innakivenko@yandex.ru;

ORCID ID: 0000-0003-2044-5456

\title{
PERFORMATIVE PARADIGM OF GRATITUDE UTTERANCES (ON THE SAMPLES OF ENGLISH LITERARY DISCOURSE)
}

Summary. The main aim of the present article is to describe the performative paradigm of gratitude utterances in English literary discourse. The object of the research is English literary role-played discourse. The subject of the study is gratitude speech act. The paper deals with the analysis of the notion (performative" and properties of performative expressions. Besides, it includes descriptions of such notions as "sematic performative» and (communicative-semantic group». Moreover, the communicative-semantic group of English expressions with the intentional meaning and illocutionary function of gratitude has been identified and the patterns realizing them have been singled out. The difference between explicit and implicit performatives has been established as well. All the above mentioned terms have been applied to gratitude speech act.

Conclusions. Gratitude speech act is to be regarded as a performative speech act. The formulae of its expression include I thank you, Thank you and Thanks. Thank you and Thanks are incomplete elliptical sentences that naturally lack deictic actants which characteristic of spoken language. Other means of expressing gratitude form a communicative-semantic group. It includes both direct and indirect conventional semantic performatives of gratitude. The intention of the latter is easily guessed by the addressee under certain extralinguistic circumstances.

Practical value of the research is a possibility to use the theoretical points of the carried out research during the lectures and seminars devoted to the problems of Speech act theory.

Key words: performative, semantic performative, speech act, gratitude, communicative-semantic group.

Статтю отримано 29.04.2017 $p$.

http://dx.doi.org/10.18524/2307-4558.2017.27.107887

УДК 811.111:808.53:347.97:343.115(73)

КУКОВСЬКА Вікторія Ігорівна,

кандидат філологічних наук, асистент кафедри англійської мови Чернівецького національного університету імені Юрія Федьковича; вул. Коцюбинського, 2, м. Чернівці, 58012, Україна; тел. +38 (0372) 584869; e-mail: vita354@rambler.ru; ORCID ID: 0000-0003-1657-1134

\section{СУДОВА ПРОМОВА: ЕКСПЛІКАЦІЙНИЙ НАРАТИВ ЧИ ПРИХОВАНИЙ ДІАЛОГ?}

Анотація. Метою статті є опис результатів вивчення монологічних і діалогічних особливостей американських судових промов, що сприяють мовленнєвій взаємодії між учасниками судового засідання. Об'єктом дослідження $\mathrm{\epsilon}$ тексти англомовних судових промов. Предмет дослідження - функціонально-смислові особливості текстової організації сучасних американських судових промов. У результаті проведеної дослідницької роботи розглянуто стильову приналежність судової промови; було зроблено уточнення щодо поняття (судова промова» з огляду її функціонально-смислових особливостей; з'ясовано напрямки дії мовленнєвого впливу між учасниками судового засідання; а також здійснено спробу визначити комунікативно-функціональну структуру судової промови. У висновках встановлено, що судова промова характеризується високим рівнем організованості та контрольованими мовленнєвими подіями, які регулюють соціальні відношення у межах судового засідання. Оскільки кількість ролей та функції учасників судової дискусії чітко визначені на законодавчому рівні, то між головними учасниками судового засідання, якими виступають як професіонали (суддя, прокурор і адвокат), так і прості громадяни (присяжні), відбувається комунікація компетивного характеру, одним з проявів якої є ораторський виступ захисника.

Ключові слова: судова промова, суддя, прокурор, адвокат, присяжні, мовленнєвий вплив.

Постановка проблеми. Сучасна парадигма гуманітарних знань передбачає вивчення мови в комунікативному аспекті, під час якого здійснюється ментальний вплив на слухача. Будь-який судовий процес - це форма мовленнєвого спілкування, де мова виступає не тільки механізмом отримання та передачі інформації, але й засобом спілкування та словесного переконання учасників судового процесу у правильності та обгрунтованості тез судових сторін. Тому змістом та головною метою судової промови є успішний мовленнєвий вплив на судову аудиторію.

Аналіз останніх досліджень і публікацій. У парадигмі сучасних юрислінгвістичних досліджень значна увага приділяється питанням ефективного застосування термінології у письмових юридичних текстах (Т. В. Новікова, I. Witczak-Plisiecka), судового наративу (W. M. O’Barr, J. M. Conley, C. Heffer), аргументативної мовленнєвої діяльності учасників судового процесу (N. Nievelle, E. T. Feteris, E. Weigand), правової та мовленнєвої взаємодії (J. Gibbons, J. Atkinson, P. Drew), 
комунікативних невдач (D. Eades), судового засідання за участю перекладача чи емігрантів (N. S. Nicolson, S. D'hondt, A. Wennerstorm), прагматичних категорій ввічливості і співпраці при судовій комунікації (G. M. Green), стратегій організації судового допиту (H. Woodbury) та ін. Проте, незважаючи на комплексні дослідження особливостей судової промови, напрямки дії мовленнєвого впливу між учасниками судового засідання в текстах американських судових промов вивчено недостатньо. Цей фокт, а також лінгво-гносеологічна важливість проблеми мовленнєвої сугестії та шляхів її реалізації під час людської комунікації визначає актуальність і перспективність цієї роботи.

Постановка завдання. Мета роботи полягає у виявленні та репрезентації монологічних і діалогічних особливостей американських судових промов, що сприяють мовленнєвій взаємодії між учасниками судового засідання. Об'єктом дослідження є тексти англомовних судових промов. Предмет дослідження - функціонально-смислові особливості текстової організації сучасних американських судових промов. Поставлена мета мотивує завдання дослідження: вивчення стильової приналежності судової промови; уточнення поняття (судова промова) з огляду її функціонально-смислових особливостей; з'ясування напрямків дії мовленнєвого впливу між учасниками судового засідання; визначення комунікативно-фрункціональної структури судової промови.

Виклад основного матеріалу. Судова промова як невід'ємна складова культури судового процесу зазвичай розглядається, з одного боку, як “окремий літературний жанр у річищі ораторської промови ) $[4$, с. 22], а з іншого - як (кримінально-процесуальна дія» [6, с. 14], яка має на меті вплинути на суд шляхом звернення до свідомості, уяви та емоцій слухачів.

Зважаючи на те, що судова промова - це публічний виступ уповноваженого учасника процесу, що звертається до суду та присяжних при розгляді кримінальної справи, вона, як стверджують дослідники $[1 ; 2 ; 10 ; 13]$, відрізняється офіційністю професійного мовлення.

Судову промову можюливо розглядати як яскравий приклад експлікованої маніфестації монологічного повідомлення, яке, на думку І. Р. Гальперіна, можливе тільки при відсутності безпосереднього контакту із співрозмовником [3, с. 70]. При цьому, монологічне мовлення, на відміну від діалогічного, характеризується своєю розгорнутістю, наявністю поширених конструкцій, їхньою граматичною оформленістю [11, с. 132].

I. Б. Морозова вважає, що в монолозі речення горизонтально взаємно зумовлені як ланки одного ланцюга [9, с. 78] і наводить наступну схему монологічного повідомлення (див. рис. 1):

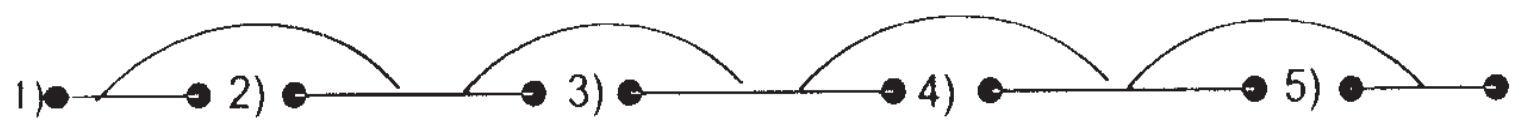

Рис. 1. Схематичне зображення монологічної послідовності

На цьому рисунку пронумеровані відрізки репрезентують речення, а дугами відображено зв'язок між горизонтально послідовними репліками.

Аналіз фактичного матеріалу дослідження показує, що будь-який судовий виступ (у даному прикладі це виступ адвоката) побудовано за аналітичним принципом. Наприклад: Now, this is the man- who is an interesting man-who details cars. He's the man who is well-known to the Prosecution. He talked to Detective Payne, almost right away during the investigation to Payne and he told Payne the same thing he told you in the course of this trial. This is what he said. He says he lives nearby and he has these two elderly dogs, one of whom I recall was 14 years of age [12].

Водночас, будь-який виступ у суді містить реальні фокти та докази, які, як і у науковому або офбіційному ораторському дискурсі, необхідні для винесення судового вироку. Проте судова промова передбачає певну міру свободи і творчості у способі подання доказів, де проявляються риси акторського мистецтва задля емоційно-особистісного впливу на аудиторію.

Звідси випливає ще одна особливість такого типу промов, а саме їхня персуазивність. Як важливий засіб правової пропаганди, судова промова здійснює значний психологічний вплив на слухачів та імплікаційно спонукає їх до прийняття певних рішень. Н. Г. Михайловська та В. В. Одінцов звертають увагу на поєднання в судовому виступі логічності розгортання думки з можюливим емоційним впливом та зазначають, що «при аналізі непрямих доказів використовуються логічні способи впливу, а якщо фабула справи зрозуміла, тоді необхідні емоційно-експресивні засоби впливул [8, с. 81].

Разом з тим, судова дія, яка розгортається на очах присяжних, розігрується її головними особами: суддею, державним обвинувачем і адвокатом / захисником. Вочевидь, у судовому процесі можна виокремити дві протилежно діючі сили. Це - прокурор, що звинувачує, і адвокат, що захищає. Якщо у промовах обвинувача виклад фоктичних обставин та оцінка звинувачувальних доказів, як правило, має негативний характер і відрізняється відповідною спрямованістю на слухачів, то адвокатський виступ містить таку інтерпретацію фактичних обставин справи, що заперечує твердження прокурора й висвітлює підзахисного в очах аудиторії з протилежного боку. Інакше кажучи, у промові захисника спостерігається виклад протилежного погляду на вже встановлені факти, виклад додаткових обставин справи та їх аналіз, позитивна характеристика особистості підзахисного, аналіз 
причин, що підштовхнули його до вчинення певних дій. Усі ці фактори спрямовані на здійснення певного ментального впливу на слухачів з метою виправдання підзахисного або пом'якшення йому міри покарання. Слід зазначити, що між усіма її учасниками тією чи іншою мірою відбувається взаємодія діалогічного характеру.

Таким чином, можна зробити висновок, що адвокатська промова у суді маніфестує певні риси, притаманні діалоговому спілкуванню, а саме безпосереднє звернення до аудиторії, постановку питань, налагодження контакту із співрозмовниками. Наприклад: But when it came down to the end, he wasn't talking about motive, was he? He was trying to talk about our time line. Why would he do that? Let's talk about why he would. Because the Defense in this case called many witnesses who corroborated each other and who shattered the Prosecution's time line. Now, these are witnesses to a person who were known by the Prosecution, but discarded by the Prosecution. Why? [12].

Узагальнимо, що, як авторський монолог, будь-яка судова промова є компонентом діалогу, який має місце між сторонами звинувачення і захисту протягом всього судового процесу. Крім того, діалог ведеться також між захисником і присяжними, прокурором і присяжними. При мовчазному схваленні чи несхваленні присяжними сторони намагаються переконати аудиторію у правильності своєї думки (див. рис. 2).

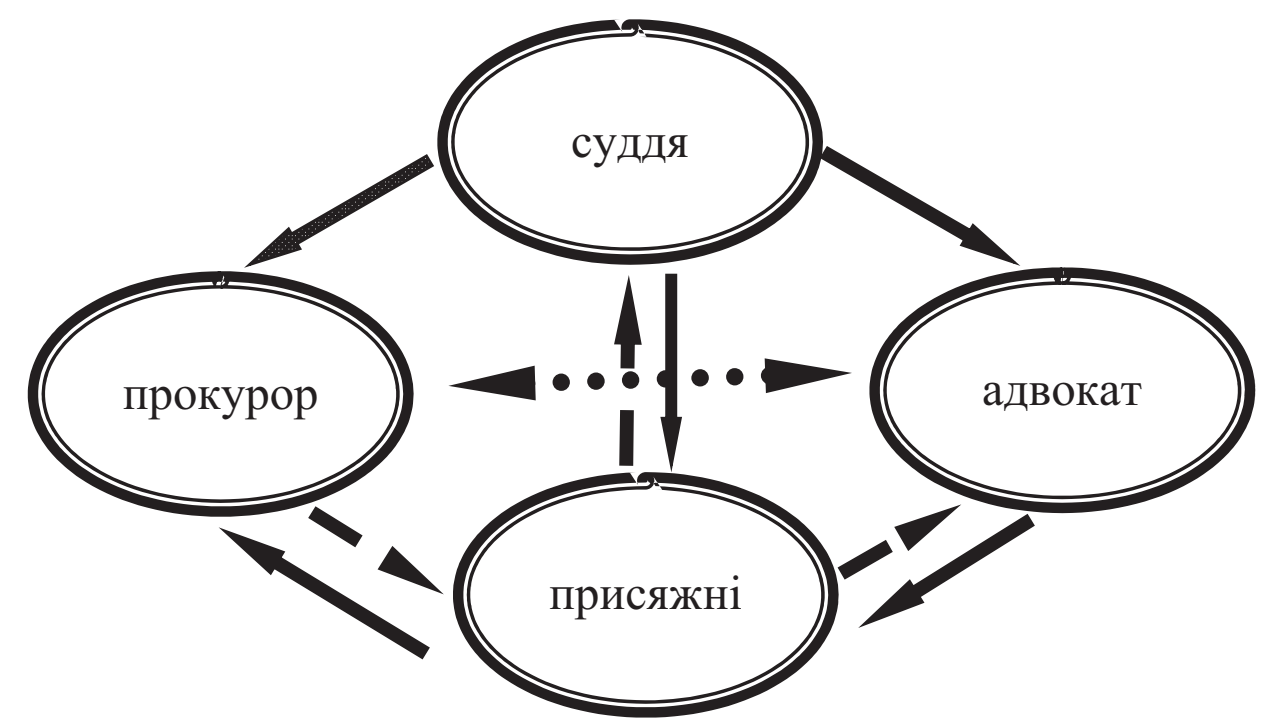

Рис. 2. Репрезентація напрямків дії мовленнєвого впливу між учасниками судового засідання, де:

прямий мовленнєвий вплив на учасників судового засідання; - непрямий вплив на учасників судо-

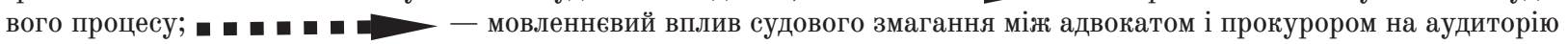

Як показано на рис. 2, суддя як голова засідання виконує роль наглядача за дотриманням норм і правил поведінки під час судового процесу, а коли порушення все ж таки відбувається, він мовленнєво впливає саме на порушника зауваженням, відновлюючи порядок у залі суду.

Водночас, судові промови прокурора та захисника за своїм змістом і побудовою спрямовані на здійснення прямого мовленнєвого впливу на свідомість присяжних за допомогою “різних засобів варіативної інтерпретації дійсності (таких як рефреймінг) та виразних засобів мови» [5, с. 199] для прийняття потрібного судовому оратору рішення. Між самим прокурором і адвокатом відбувається сугестивний вплив судового змагання, що визначає подальший вибір ними тих чи інших тактик досягнення своєї мети. Паралельно присяжні здійснюють непрямий вплив на суддю (наприклад, прохання про перерву), керуючи процесом судового засідання. Соціально-демографічні особливості присяжних, їх сприйняття чи несприйняття промов судових ораторів також непрямо впливають на подальшу побудову аргументативного обвинувачення та захисту.

Важливу роль при цьому відіграє комунікативно-ффункціональна структура промови. Як зазначає Л. Г. Киркунова, судова промова розпадається на певні композиційні блоки: інформаційний (передача загальної інформації), комунікативний (встановлення і підтримка контакту з аудиторією), змішаного характеру (передача додаткової інформації) [7, с. 300-302]. У цілому, погоджуючись 3 підходом дослідниці, зауважимо, що вона оминає таку невід'ємну складову судової промови як емоційно-впливову чи сугестивну.

Зі свого боку, вважаємо, що судова промова складається з трьох частин: перша - пояснення реального статусу справи, друга — об'єктивна законна оцінка злочину і третя - суб'єктивне ставлення до винуватості чи невинуватості підзахисного. Отже, з погляду мовленнєвої організації, судову промову можна розглядати як сукупність певних мікротем або тематичних вузлів. «При цьому кожен 
тематичний вузол має значеннєву завершеність і синтаксично виражається у вигляді певного набору діалогічних єдностей) [ $[9$, с. 125]. Тому наявні у промові тематичні вузли заздалегідь побудовані так, що можна сформувати у слухачів певне враження про судову справу взагалі і винуватість / невинуватість підзахисного. Композиція промови демонструє послідовність методу демонстрації думки згідно плану, що висвітлює послідовність процесуального доказу та віддзеркалює найбільш загальні принципи побудови персуазивного впливу. Звідси слідує, що якщо формально судова промова спрямована на виявлення фактичних обставин справи, то реально йдеться про налаштування суду присяжних на прийняття вигідного для мовця рішення.

Висновки. Отже, судова промова поєднує ознаки, з одного боку, інституційного дискурсу, з іншого - персонального. Незважаючи на поверхово монологічний вигляд, будь-яка судова промова є компонентом прихованого діалогу, що відіграє важливу роль в обвинуваченні та захисті протягом усього судового процесу. 3 іншого боку, діалог ведеться між прокурором і присяжними, адвокатом і присяжними. В умовах мовчазного схвалення / несхвалення дій підзахисного сторони намагаються переконати присяжних у своїй позиції. Основна частина судової промови на комунікативному рівні є сукупністю певних тематичних вузлів, тому наявні у промові тематичні вузли заздалегідь побудовані так, щоб сформувати у слухачів певне враження про винуватість / невинуватість підзахисного.

Перспективою подальших досліджень ми вважаємо компаративне вивчення різнорівневих мовних засобів у промовах державного обвинувача та захисника та їхньої ролі у забезпеченні мовленнєвого впливу на учасників судового процесу.

\section{Лime ратура}

1. Володина С. И. К вопросу о юридической риторике и стилях судебной адвоката / С. И. Володина // Российская юстиция. - М., 2006. - № 4 . - С. 61-63.

2. Володина С. И. К вопросу об особенностях защитительной речи / С. И. Володина // Lex Russica. Научные труды МГЮА. - М., 2006. - № 3. - С. 584-600.

3. Гальперин И. Р. Очерки по стилистике английского языка / И. Р. Гальперин. - М. : Русский язык, 1981. $459 \mathrm{c.}$

4. Дубровская T. В. К дискуссии о методике построения защитительной речи : коммуникативно-прагматические блоки и тактики (на материале английского языка) / Т. В. Дубровская // Юрислингвистика. - М., 2012. № 1 (12). - C. 21-31.

5. Каракозов C. А. Психологические аспекты выступления адвоката в прениях сторон в суде присяжных / С. А. Каракозов $/ /$ Бизнес в законе. - М. : Изд. Дом “Юр-ВАК», 2009. - № 4. - С. 194-199.

6. Kaщавеив $P$. C. Судові промови державного обвинувача та адвоката-захисника у кримінальному судочинстві України : правові, етичні, логічні та мовні аспекти : [монографія] / Р. С. Кацавець. - К : ЦУЛ, 2014. - 150 с.

7. Кㅎкунова Л. Г. Судебная речь : методика работы над композицией / Л. Г. Кыркунова // Юрислингвистика. М., 2010. - № $10:$ Лингвоконфоликтология и юриспруденция. - С. 299-305.

8. Михайловская Н. Г. Искусство судебного оратора / Н. Г. Михайловская, В. В. Одинцов. - М. : Юрид. лит., 1981. $-176 \mathrm{c}$.

9. Морозова I. Б. Парадигматичний аналіз структури і семантики елементарних комунікативних одиниць у світлі гештальт-теорії в сучасній англійській мові : [монографія] / Морозова І. Б. - Одеса : Друкарський дім, 2009. - 384 с.

10. Попова T. Г. Об особенности судебной речи / Т. Г. Попова, М. Н. Федулова // Вестник Южно-Уральского государственного университета. Серия : Лингвистика. - Челябинск, 2010. - № 1 (177). - С. 57-59.

11. Розенталь Д. Э. Словарь-справочник лингвистических терминов / Д. Э. Розенталь, М. А. Теленкова. - М. : Астрель, АСТ, 2001. - $624 \mathrm{c.}$

12. Closing argument of Johnnie Cochran [Electronic resource]. - Mode of access : URL : http://simpson.walraven. org/sep27.html. - Title from the screen.

13. Model Rules of Professional Conduct / [published by American Bar Association]. - American Bar Association, 2012. $-294 \mathrm{p}$.

\section{References}

1. Volodina, S. I. (2006), "On the issue of legal rhetoric and styles of the court speech of a lawyer", Russian justice [“K voprosu o juridicheskoj ritorike i stiljakh sudebnoj rechi advokata», Rossijskaja justicija], Moscow, vol. 4, pp. 61-63.

2. Volodina, S. I. (2006), "On the issue of the features of protective speech", Lex Russica ["K voprosu ob osobennostjakh zashhititel'noj rechi), Lex Russica. Nauchnye trudy MGJuA], Moscow O. Ie. Kutafin State Law University, vol. 3, pp. 584-600.

3. Gal'perin, I. R. (1981), Essays on the style of English [Ocherki po stilistike anglijskogo jazyka], Russkij jazyk, Moscow, $459 \mathrm{p}$.

4. Dubrovskaja, T. V. (2012), «To a discussion on the method of constructing protective speech : communicative and pragmatic blocks and tactics (based on the English language material)", Legal Linguistics ["(K diskussii o metodike poslingvistika], Moscow, vol. 1 (12), pp. 21-31.

5. Karakozov, S. A. (2009), "Psychological aspects of advocacy in a jury trial”, Business in law ["Psikhologicheskie aspekty vystuplenija advokata v prenijakh storon v sude prisjazhnykh", Biznes v zakone], Publishing House "Jur-VAK", Moscow, 2009, vol. 4, pp. 194-199. 
6. Kacavec', R. S. (2014), Judicial speeches of the state prosecutor and the counsel for the defense in criminal justice in Ukraine : legal, ethical, logical and linguistic aspects : monograph [Sudovi promovy derzhavnogo obvynuvacha ta advokata-zakhysnyka u kriminal'nomu sudochynstvi Ukraïny : pravovi, etychni, lohichni ta movni aspekty : monohrafija], CUL, Kyiv, $150 \mathrm{p}$.

7. Kyrkunova, L. G. (2010), "Judicial speech: the method of work on the composition»,Legal Linguistics [ Sudebnaja rech' : metodika raboty nad kompoziciej», Jurislingvistika : Lingvokonfliktologija i jurisprudencija], Moscow, vol. 10, pp. 299-305.

8. Mikhajlovskaja, N. G., Odincov, V. V. (1981), The skill of the judicial speaker [Iskusstvo sudebnogo oratora], Juridicheskaja literature, Moscow, $176 \mathrm{~s}$.

9. Morozova, I. B. (2009), Paradigmatic analysis of the elementary communicative units structure and semantics: monography [Paradygmatychnyj analiz struktury $i$ semantyky elementarnykh komunikatyvnykh odynyc' u svitli geshtal't-teoriï v suchasnij anglijs'kij movi : monohrafija], Drukars'kyj dim, Odessa, $384 \mathrm{p}$.

10. Popova, T. G., Fedulova, M. N. (2010), "On the features of judicial speech", Bulletin of South Ural State University. Series "Linguistics» ["Ob osobennosti sudebnoj rechi”, Vestnik Juzhno-Ural'skogo gosudarstvennogo universiteta. Serija : Lingvistika], SUSU, Cheljabinsk, vol. 1 (177), pp. 57-59.

11. Rozental', D. E., Telenkova, M. A. (2001), Dictionary-reference of linguistic terms [Slovar'-spravochnik lingvisticheskikh terminov], Astrel', AST, Moscow, 624 p.

12. Closing argument of Johnnie Cochran, available at : http://simpson.walraven.org/sep27.html.

13. Model Rules of Professional Conduct (2012), American Bar Association, $294 \mathrm{p}$.

\section{КУКОВСКАЯ Виктория Игоревна,}

кандидат филологических наук, ассистент кафедры английского языка Черновицкого национального университета имени Юрия Федьковича; ул. Коцюбинского, 2, г. Черновцы, 58012, Украина; тел. +38 (372) 584869;

e-mail: vita354@rambler.ru ; ORCID ID: 0000-0003-1657-1134

\section{СУДЕБНАЯ РЕЧЬ: ЭКСПЛИКАЦИОННЫЙ НАРРАТИВ ИЛИ СКРЫТЫЙ ДИАЛОГ?}

Аннотация. Целью статьи является изучение монологических и диалогических особенностей американских судебных выступлений, способствующих речевому взаимодействию между участниками судебного заседания. Объектом исследования являются тексты англоязычных судебных речей. Предмет исследования - функционально-смысловые особенности текстовой организации современной американской судебной речи. В результате проведённой исследовательской работы рассмотрена стилевая принадлежность судебной речи; было сделано уточнение понятия «судебная речь» с учётом её функционально-смысловых особенностей; сделаны попытки выяснить направления речевого воздействия между участниками судебного заседания и определить коммуникативно-функциональную структуру судебной речи. В выводах установлено, что судебная речь характеризуется высоким уровнем организованности и контролируемыми речевыми событиями, которые регулируют социальные отношения в рамках судебного заседания. Поскольку количество ролей и функции участников судебной дискуссии строго определены на законодательном уровне, то между главными участниками судебного заседания, в роли которых выступают как профессионалы (судья, прокурор и адвокат), так и простые граждане (присяжные), происходит коммуникация компетитивного характера, одним из проявлений которой является ораторское выступление защитника.

Ключевые слова: судебная речь, судья, прокурор, адвокат, присяжные, речевое воздействие.

Viktoria I. KUKOVSKA,

Candidate of Philology (PhD), Assistant Professor of the Department of English of Yuriy Fedkovych Chernivtsi

National University; 2, Kotsyubinsky Str., Chernivtsi, 58012, Ukraine; tel.: +38 (0372) 584869;

e-mail: vita354@rambler.ru; ORCID ID: 0000-0003-1657-1134

\section{JUDICIAL SPEECH: AN EXPLICATIVE NARRATIVE OR A HIDDEN DIALOGUE?}

Summary. The article is devoted to the study of monologic and dialogical features of American judicial speeches, which facilitate speech interaction between the participants of the court session. The subject of the study are the English texts of judicial speeches. The subject of the study are the functional and semantic features of the textual organization of modern American judicial speeches. In the given paper the style belonging of the judicial speech is considered; the concept of (judicial speech" is clarified, taking into account its functional and semantic features; the directions of the speech impact between the participants of the court session are clarified; and an attempt to determine the communicative and functional structure of judicial speech is made. As a result of the conducted research it has been established that the judicial speech is characterized by a high level of organization and controlled speech events that regulate social relations within the court session. Since the number of roles and functions of the participants in the judicial discussion is clearly defined at the legislative level, a communication of a competing nature is conducted between the main participants of the court session, which are both professionals (judge, prosecutor and defense attorney) and ordinary citizens (juries), one of the manifestations of which is an oratory by a defense counsel.

Key words: judicial speech, judge, prosecutor, defense counsel, jury, verbal influence.

Статтю отримано 5.05.2017 p. 